Тараненко С.В., Пріступа С.В., Колесник В.В., Пастух О.В., Гойжсевський О.В.

\title{
УПРАВЛІННЯ ГРЕБНИМИ ЕЛЕКТРОРУШІЯМИ ПРИ ПЛАВАННІ В УМОВАХ ХИТАВИЦІ
}

У статті розглянуто питання управління судном з електрорушієм в умовах хитавиці. При ході судна в умовах хвилювання зміна моменту генератора така, щуо дизель працює в режимах перевантаження з різкою зміною механічних моментів, а навантаження на електрорушій, викликане квазівипадковою хитавищею, значно скорочує експлуатаційні характеристики пропульсивного комплексу. В статті визначено основні фактори, впливаючи на різку зміну навантаження на електрорушій та проаналізовано можливості управління стохастичними процесами за допомогою технології нечіткої логіки. Аналіз хитавиці судна, вказує на випадковий характер постійно діючого обурення різної величини $і$ тривалості. При роботі ГЕУ в таких умовах мають місие коливання моменту опору на гребному валу (якщо відсутне відповідне регулювання збудження ГЕД), моментів опору на валах дизелів, що визначаються електромагнітними моментами генераторів. Квазістаціонарний характер зміни Мг пояснюється таким же характером зміни моменту опору обертанню гребного гвинта. Характер корелячійних функцій свідчить про ергодичності прочесу. Стабілізація кутової швидкості зміною упору лопатей азіподу (ГРК) дає можливість уникнути перевантаження, а, отже оптимізувати закон управління ГРК.

Ключові слова: управління гребними електродвигунами, нечітка логіка, закони управління

\section{Постановка проблеми}

При роботі ГЕУ в динамічних режимах, наприклад, при ході судна на хвилюванні, можуть виникати неприпустимі навантаження, здатні викликати аварію первинних двигунів. Дизелі вкрай чутливі до перевантажень. Вони здатні витримати перевантаження по потужності не більше ніж на 10\% протягом не більше 1 години. При ході судна в умовах хвилювання зміна моменту генератора така, що дизель працює в діапазоні від режимів, відповідних їх зовнішній характеристиці при перевантаженні, до режимів, відповідних нульовій подачі палива. Це видно з розгляду кривої ходу паливної рейки, яка часто протягом декількох секунд (більше трьох) знаходиться в положенні упору або ж відкидається до положення, відповідного відсіченні подачі палива.

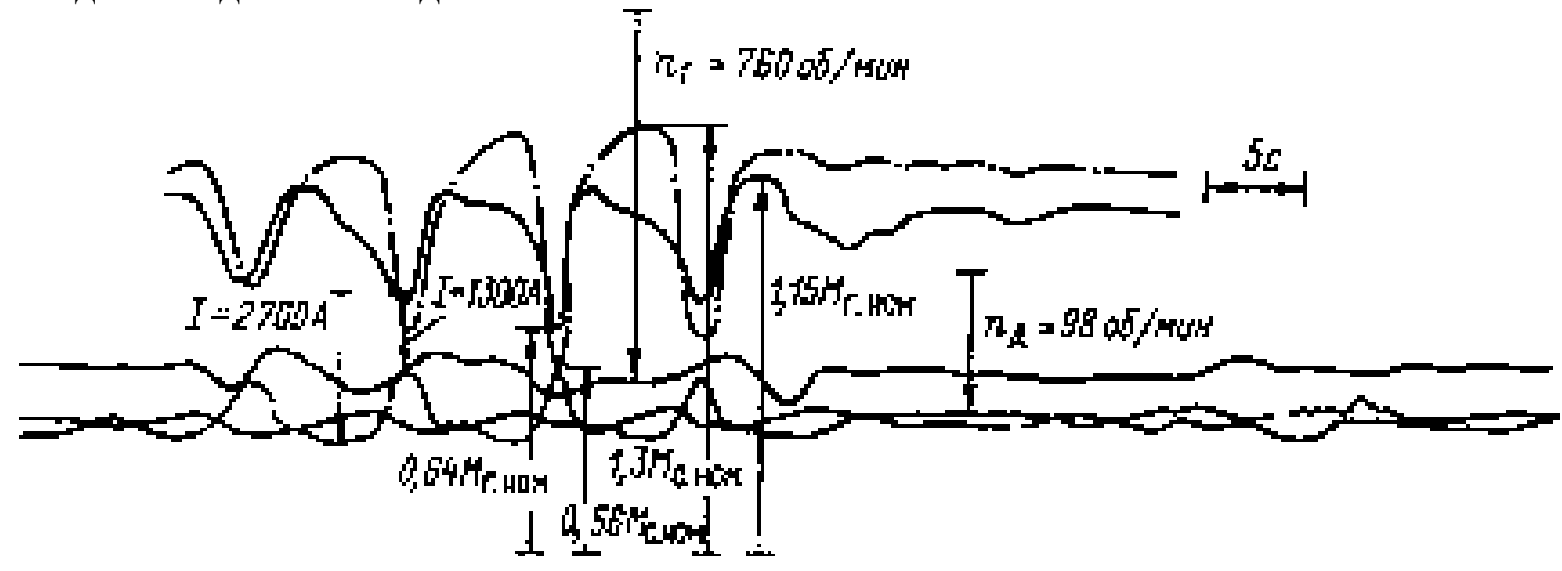

Рис. 1. Зміна параметрів ГЕУ при ході в умовах хвилювання 
Аналіз останніх досліджень і публікацій. Дослідженням перехідних процесів у системі управління гребними електрорушіями приділили увагу Яровенко В.А., Черников П.С., Варбанец Р.А., Зарицкая Е.И., Подлях А.Е. та інші.

Мета дослідження полягає в знаходженні такого закону управління, який би зменшив коливання визначених параметрів (кутова швидкість, напруга, потужність) гребного електрорушія.

Основні результати дослідження. Коливання струму головного ланцюга призводять до істотних коливань моменту опору на валу дизеля, що визначається в основному електромагнітним моментом генератора Мг. Коливання моменту генератора знаходяться в межах $(1,15-0,64)$ Мг.ном. Таким чином, при хитавиці судна система збудження 3 трьохобмотковим збудником генераторів, що реалізує лише одну жорстку лінію зворотнього зв'язку по току головного ланцюга і не має автоматичного регулювання збудження ГЕД, не забезпечує сприятливу роботу дизель-генераторів. Зазначене може призвести до аварій окремих вузлів і перш за все дизелів ГЕУ. На рис. 2 приведена осцилограма роботи ГЕУ виробничого рефрижератора «Буревісник» при ході судна в умовах п'ятибального хвилювання 3 періодом качки 5 с. У схему головного струму включені два дизельгенератора. Діапазон коливань основних параметрів становить: частоти обертання дизеля$(0,95-1,08)$, частоти обертання ГЕД - $(0,96-1,16)$, струму головного ланцюга - $(0,644-1,18)$ напруги генератора- $(0,914-1,12)$ Uг.ном.

Ідеальною системою автоматичного управління ГЕУ, що забезпечує відсутність перевантажень при роботі в умовах взаємодії гребного гвинта 3 водою, буде система, при якій в будь-який момент роботи ГЕУ виконується рівняння $\mathrm{P}=\mathrm{kMдNд} \mathrm{=} \mathrm{const,} \mathrm{де} \mathrm{Мд-}$ момент ГЭД; Nд — частота обертання ГЭД; $\mathrm{k}$ - коефіцієнт пропорційності. При роботі ГЕУ в таких умовах мають місце коливання моменту опору на гребному валу (якщо відсутнє відповідне регулювання збудження ГЕД), моментів опору на валах дизелів, що визначаються електромагнітними моментами генераторів. Квазістаціонарний характер зміни Мг пояснюється таким же характером зміни моменту опору обертанню гребного гвинта. Характер кореляційних функцій свідчить про ергодичності процесу (рис. 3).

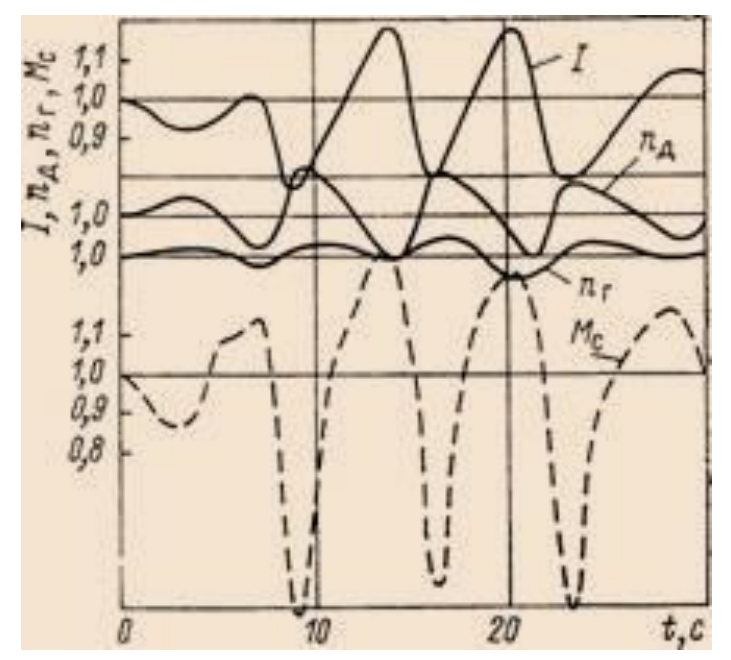

Рис. 2. Осцилограма роботи ГЕУ виробничого рефрижератора «Буревісник» при ході судна в умовах п'ятибального

хвилювання 3 періодом качки 5 с

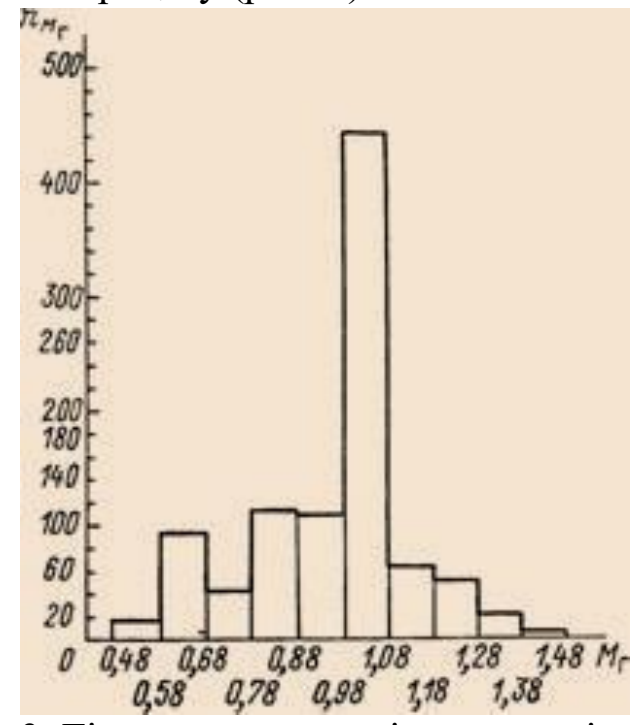

Рис. 3. Гістограма розподілу моментів генератора ГЕУ при хитавиці судна

Розподіл моментів генератора характеризує симетрію можливих моментів по відношенню до середнього значення. Частоту їх появи Nм наближено можна описати нормальним законом розподілу випадкової величини, що свідчить про близькість до стаціонарного процесу, причому частота появи моментів $\mathrm{m}<\mathrm{m}(\mathrm{t})$ більш імовірна, ніж частота появи моментів $\mathrm{m}>\mathrm{m}(\mathrm{t})$. 
Так як, і Мд і д випадкові величини, доцільно застосувати методологію нечіткої логіки.

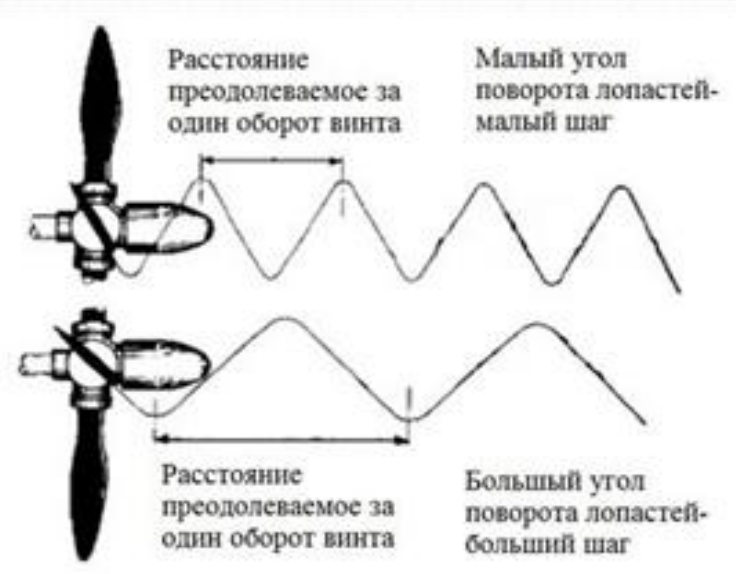

Рис. 4. Характеристика ГРК
Стабілізація частоти обертання $\mathrm{N}$ д забезпечується двома засобами: зміною кута установки лопатей ВРШ і ступенем заповнення мастилом порожнини гідромуфти. Застосуємо перший варіант. Гвинт регульованого кроку (ГРК, ВРШ) - це гребний гвинт, у якого регулюється кут розвороту лопатей. Лопаті такого гвинта розгортаються спеціальним механізмом в будь-яке положення в діапазоні “повний вперед - стоп-повний назад”. В залежності від ступеня розвороту лопатей, не змінюючи роботи головного двигуна, судну можна надати або рух вперед, або зупинитися на місці, або створити рух назад.

При експлуатації всіх видів ГРК застосовується принципово однакова система управління. Гідравлічна система управління ГРК дає можливість широко використовувати в якості головного двигуна нереверсивні силові установки (турбіни, дизелі великої потужності і т. д.).

Впровадження ГРК на судах дозволяє поліпшити маневрені якості судів. До них в першу чергу відноситься зменшення гальмівного шляху (за рахунок швидкого перекладу лопатей гвинта на режим роботи заднього ходу) і періоду гальмування. Гасіння інерції починається майже негайно після дачі команди “Назад повний " (окремі суду 3 повного ходу зупиняються за 1 хв при гальмівному шляху 1-1,5 корпусу). На судах з ГРК полегшується виконання багатьох видів маневрів при зйомці з якоря і постановці на якір, при швартуванні судна до причалу і лагом до іншого судна, при розбіжності судів для запобігання зіткнень і т. д. Змоделюємо різні ситуації і це буде система правил нечіткого виведення.

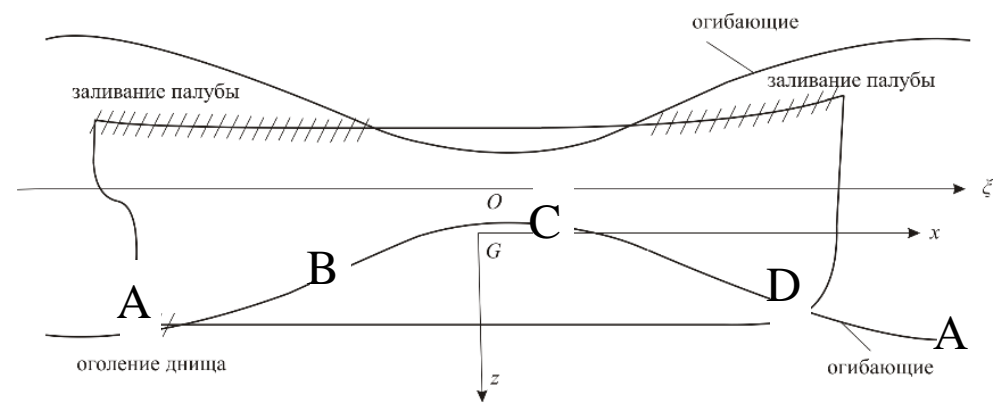

Рис. 5. Характеристика хитавиці:

А - оголення днища, вихід ГРК на поверхню;

В - розгін корпусу судна по хвилі з частковим зануренням ГРК;

$\mathrm{C}$ - найбільше занурення носу та корми судна (ГРК), заливання палуби;

$\mathrm{D}$ - підйом на хвилю з найбільшим опором судну.

Враховуючи рівняння електричної машини необхідно зі зміною моменту опору (Мc) змінювати момент сили (ГРК) зміною кута гвинтів.

Для обчислень задаємо правила вхідних та вихідних змінних величин (рис. 6), а саме кут диференту судна від -10 до +10 (можливо змінювати величину, в залежності від району плавання та фізико-кліматичних особливостей формування морських хвиль хитавиці), а також кутову швидкість гвинту регульованого кроку (омега) в межах 20\% від номінальної величини (150 об/хв).

Крім цього, вихідною величиною будемо вважати, кут ГРК, який змінюється в межах від 30 до 40 град. В результаті обчислень маємо поверхню управління ГРК (кут гвинтів) (рис. 7). 


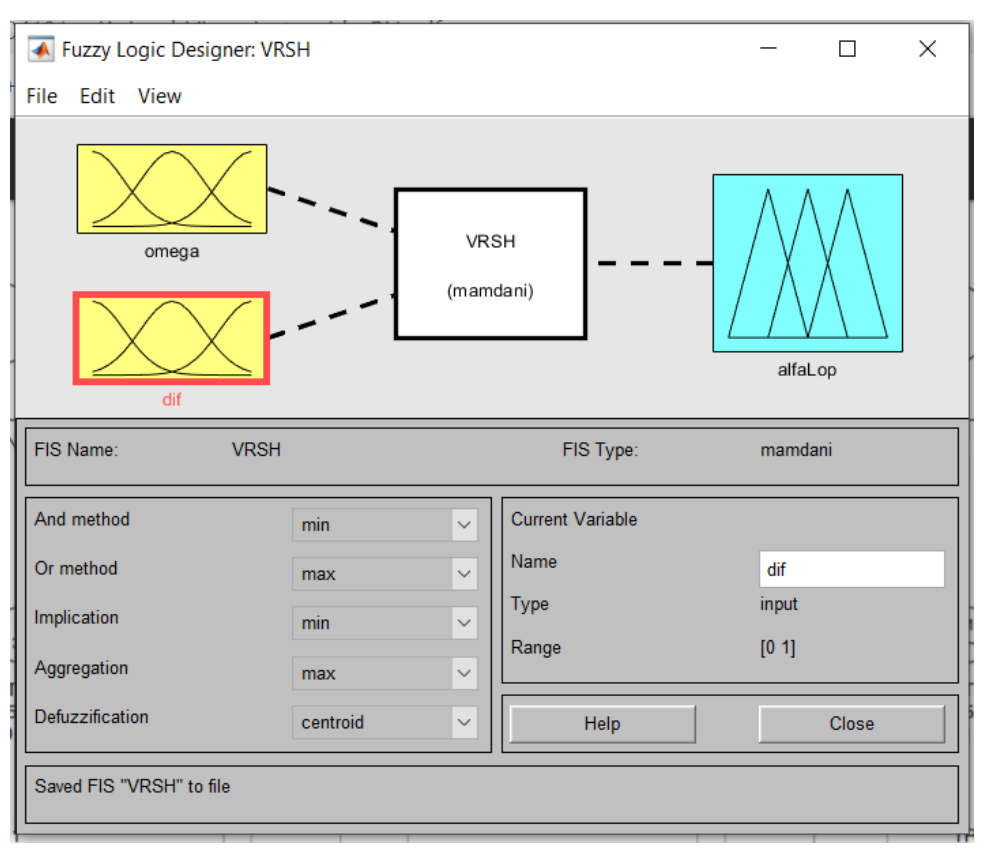

Рис.6. Умови, які впливають на роботу ГРК

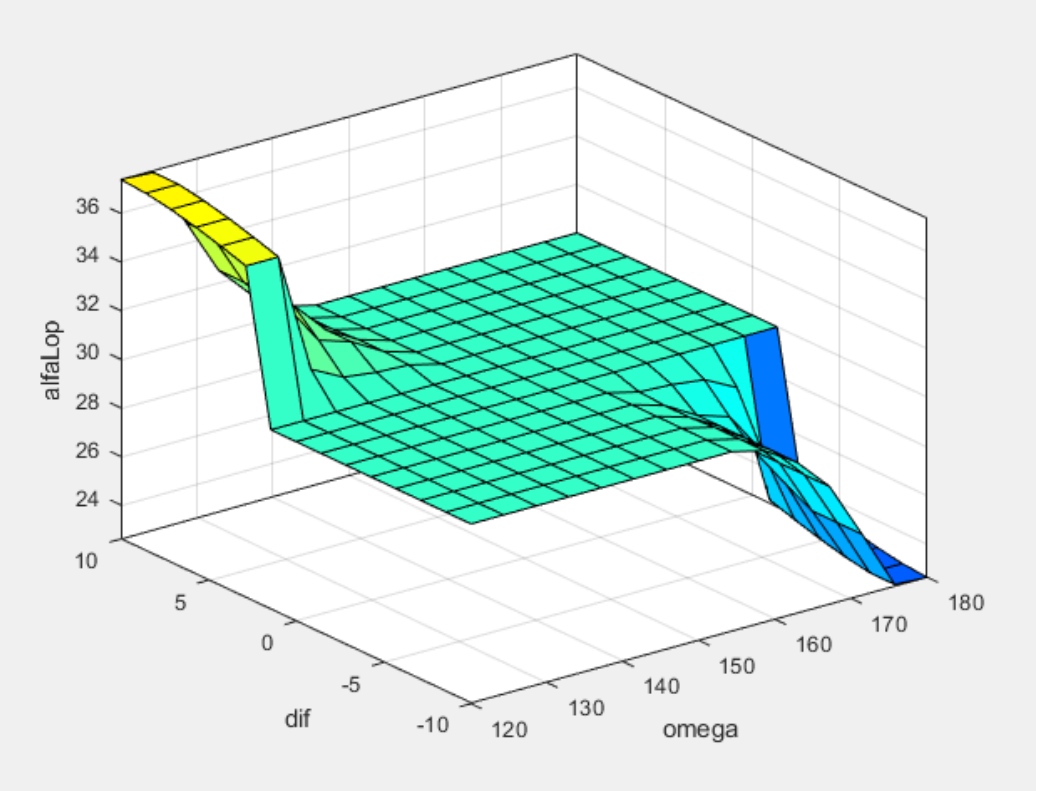

Рис. 7. Поверхня управління кутом ГРК

\section{Висновок}

Стабілізація роботи електрорушійної установки при плаванні в умовах хитавиці можлива з використанням технологій нечіткої логіки, в тому числі за рахунок зміни кута ГРК.

\section{ЛIТЕРАТУРА}

1. Оптимальное управление гребными электродвигателями электроходов при реверсировании / В.А. Яровенко, П.С. Черников, Р.А. Варбанец, Е.И. Зарицкая // Електротехніка і електромеханіка. - 2018. - № 6. - С. 38-46.

2. Яровенко В.А., Черников П.С. Метод расчета переходных режимов гребных электроэнергетических установок // Електротехніка і електромеханіка. - 2017. - №6. C. 32-41.

3. Яровенко В.А. Расчет и оптимизация переходных режимов пропульсивных комплексов электроходов. - Одесса: «Маяк», 1999. - 188 с.

4. Дьяконов В., Круглов В. Математические пакеты расширения MATLAB. Специальный справочник. СПб: Питер, 2001. 480 с. 
5. Гультяев А. Визуальное моделирование в среде MATLAB: учебный курс. СПб: Питер. 2000. $432 \mathrm{c}$.

6. Искусственный интеллект. Кн. 2. Модели и методы: Справочник I Под ред. д. А.Поспелова. М.: Радио и связь, 1990. 304 с.

7. Клини С. Математическая логика. . М.: Мир, 1973. 480 с.

8. Ковальски Р. Логика в решении проблем. М.: Наука. 1990. 280 с.

9. Кофман А. Введение в теорию нечетких множеств. М.: Радио и связь, 1982. 432 с.

10. Черников П.С., Яровенко В.А., Зарицкая Е.И. Влияние параметров электроходов на показатели качества работы электроэнергетических установок при маневрировании // Вісник НТУ «ХПІ». Серія «Електричні машини та електромеханічне перетворювання енергії». - 2018. - №5(1281). С. 46-54.

\section{REFERENCES}

1. Optimal control of electric propulsion electric motors during reversing / V.A. Yarovenko, P.S. Chernikov, R.A. Varbanets, E.I. Zaritskaya // Electrical engineering and electrical engineering. - 2018. - No. 6. - S. 38-46.

2. Yarovenko V.A., Chernikov P.C. The method of calculating the transient conditions of rowing electric power plants // Elektrotehnika i elektromekhanika. - 2017. - No. 6. - S. 32-41.

3. Yarovenko V.A. Calculation and optimization of transient modes of propulsive complexes of electric ships. - Odessa: "The Lighthouse", 1999. - 188 p.

4. Dyakonov V., Kruglov V. Mathematical expansion packages MATLAB. Special reference. St. Petersburg: Peter, 2001.480 s.

5. Gultyaev A. Visual modeling in MATLAB: a training course. SPb: Peter. $2000.432 \mathrm{~s}$.

6. Artificial intelligence. Prince 2. Models and Methods: Handbook I Ed. D. A. Pospelova. M .: Radio and communications, 1990. 304 p.

7. Wedges S. Mathematical Logic. . M.: Mir, $1973.480 \mathrm{~s}$.

8. Kowalski R. Lorika in solving problems. M .: Science. $1990.280 \mathrm{~s}$.

9. Kofman A. Introduction to the theory of fuzzy sets. M .: Radio and communication, 1982. $432 \mathrm{p}$.

10. Chernikov P.S., Yarovenko V.A., Zaritskaya E.I. The influence of parameters of electric ships on the performance indicators of electric power plants during maneuvering // Visnik NTU "KhPI". Seria "Electric Machines and Electric Power Engineering". - 2018.- No. 5 (1281). S. 46-54.

\section{Taranenko S.V., Pristupa S.V., Kolesnyk V.V., Pastukh O.V., Goyzhevsky O.V. CONTROL OF ROWING ELECTRIC MOVEMENTS WHEN SWIMMING IN THE CONDITIONS}

The article considers the issue of control of a ship with electric propulsion in the conditions of oscillation. When the vessel is moving in excitement, the change in the torque of the generator is such that the diesel engine operates in overload modes with a sharp change in mechanical torques, and the load on the electric propulsion caused by quasi-random oscillation significantly reduces the performance of the propulsion system. The article identifies the main factors influencing the sharp change in the load on the electric motor and analyzes the possibilities of controlling stochastic processes using fuzzy logic technology. Analysis of the ship's oscillation indicates the random nature of the constant disturbance of varying magnitude and duration. During operation of GEU in such conditions there are fluctuations of the moment of resistance on a propeller shaft (if there is no corresponding regulation of excitation of GED), the moments of resistance on shafts of diesels which are defined by electromagnetic moments of generators. The quasi-stationary nature of the change in $\mathrm{Mg}$ is explained by the same nature of the change in the moment of resistance to rotation of the propeller. The nature of correlation functions indicates the ergodic nature of the process. Stabilization of the angular velocity by changing the stop of the blades of the azipod (GRP) makes it possible to avoid overload and, therefore, to optimize the control law of the GRP.

Keywords: control of rowing motors, fuzzy logic, control laws. 